\title{
Industri Halal di Aceh: Strategi dan Perkembangan
}

\section{Ramadhan Razalia ${ }^{1 *}$, Angga Syahputraa ${ }^{1}$, Almira Keumala Ulfah ${ }^{1}$}

Fakultas Ekonomi dan Bisnis Islam (FEBI) Institut Agama

Islam Negeri Lhokseumawe

*Corresponding author:

anggasyahputra@iainlhokseumawe.ac.id

\author{
Article history
}

Received, 29 March 2021

Revised 1, 22 April 2021

Accepted, 14 July 2021

This study aims to analyze the strategy and development of the halal industry in the province of Aceh. This research is a qualitative research, using a literature review approach from various previous studies. uses secondary data obtained from journals, documentation, and reports from related parties such as the literally Central Agency on Statistics, LPPOM MPU, LPPOM MUI, Aceh Culture and Tourism Office and related parties. The results of the study found that Aceh Province is one of the provinces that implements sharia in all sectors. The application of Islam is not only in banking, but is also applied to tourism, food and other halal industries, however, the optimization of the halal industry cannot be felt optimally. The development of a halal industry strategy needs support from the local government. One strategy that must be done is to issue a halal certificate easily but professionally. In addition, to maximize the halal industry, especially halal tourism, local governments must also pay attention to the existing infrastructure. With the maximum development strategy carried out, it is expected to increase the halal industry, especially halal tourism in Aceh Province.

Keyword: Halal industry, aceh province, strategy and development, halal food, halal tourism

\section{Abstrak}

Penelitian ini bertujuan untuk menganalisis strategi dan perkembangan halal industri di provinsi aceh. Penelitian ini merupakan penelitian kualitatif. Penelitian ini menggunakan data sekunder yang diperoleh dari jurnal, buku dokumentasi, dan laporanlaporan yang berasal dari pihak terkait seperti Badan Pusat Statistik, LPPOM MPU, LPPOM MUI, Dinas Kebudayaan dan Pariwisata Aceh dan pihak-pihak terkait. Hasil penelitian menemukan bahwa Provinsi Aceh merupakan salah satu provinsi yang menerapkan syariah di segala sektor. Penerapan keIslaman tidak hanya di perbankan saja, melainkan juga diterapkan pada wisata, makanan dan industri halal lainnya, namun, optimalisasi industri halal belum dapat dirasakan secara optimal. Pengembangan strategi industry halal perlu dukungan dari pemerintah daerah. Salah satu strategi yang harus dilakukan adalah mengeluarkan sertifikat halal dengan mudah namun profesional. Selain itu, untuk memaksimalkan industri halal terutama wisata halal, pemerintah daerah juga harus memperhatikan infrastruktur yang ada. memaksimalkan strategi pengembangan, diharapkan dapat meningkatkan industri halal terutama wisata halal di Provinsi Aceh.

Kata kunci: Industri Halal, Provinsi Aceh, Strategi dan Perkembangan, makanan halal, wisata halal

Cite this article:

Razalia, Ramadhan., Syahputra, Angga., Ulfah, A.K (2021). Industri Halal di Aceh: Strategi dan Perkembangan, Jurnal AlQardh, 6(1), 17-29. https://doi.org/10.23971/jaq.v6i1.2733

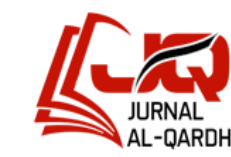

pISSN: $2354-6034$ eISSN: 2599 - 0187 


\section{Pendahuluan}

Dalam beberapa tahun terakhir pertumbuhan industri halal menduduki posisi teratas dalam laporan ekonomi. Walaupun wabah covid 19 melanda Negara Indonesia pada akhir 2019, laporan Bank Indonesia menyebutkan bahwa kurva Industri halal tetap stabil pada tingkat $2.1 \%$. Hal serupa juga disebutkan oleh LPPOM MUI bahwa jumlah perusahaan halal meningkat dari tahun 2018 sampai tahun 2019. jumlah produk yang diproduksi pada tahun 2019 mencapai 274.496 dapat dilihat pada tabel di bawah ini:

Table 1. Data Sertifikasi Halal LPPOM MUI

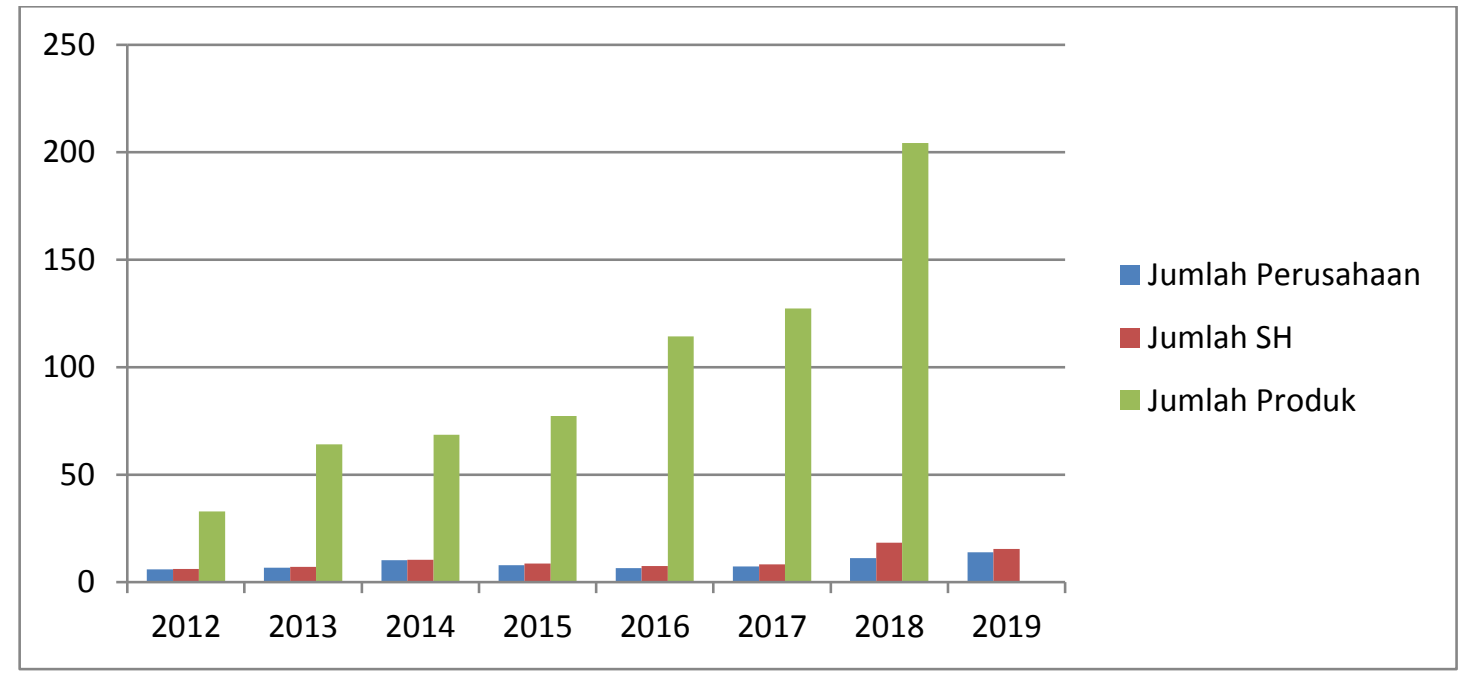

Sumber: halalmui.org (data sudah diolah)

Tabel di atas menunjukkan bahwa kurva produk halal meningkat setiap tahun. Faktanya, Industri halal tidak hanya berkembang pesat dinegara Muslim. Namun, Industri halal juga menjadi "primadona" di negara minoritas Muslim. Perkembangan yang pesat mengkonstruk paradigma bahwa Industri halal berpeluang dalam menunjang pertumbuhan ekonomi. Menurut Henderson, pertumbuhan Industri Halal tidak hanya berdampak pada sektor pariwisata saja, melainkan berimplikasi terhadap perkembangan travel dan kesehatan. ${ }^{1}$

Di Aceh sendiri, potensi pariwisata halal sangat besar. Dari data yang disajikan oleh BPS dapat dianalisis bahwa pariwisata halal di Aceh mengalami peningkatan dari tahun ke tahun (yoy). Menurut Rahmat meskipun pariwisata Aceh meningkat, daya tarik wisata aceh belum mampu menyedot pengunjung baik dalam negeri dan luar negeri untuk datang secara khusus dengan tujuan berwisata (tourism and leisure purpose). Kurangnya daya tarik tersebut dilihat dari indeks provinsi dengan pariwisata tertinggi, dan Aceh tidak termasuk didalamnya. ${ }^{2}$

Oleh karena itu, untuk mengoptimalkan industri halal di Aceh, pemerintah daerah harus memberikan perhatian, upaya dan komitmen ekstra dalam pengembangan industri halal. ${ }^{3}$ Dengan optimalnya pengembangan industri halal diharapkan dapat menjadi roda perekonomian dan jantung perekonomian bagi masyarakat sekitar. Berbeda dengan di Aceh pada umumnya, di Lhokseumawe sendiri, industri halal merupakan hal yang tabu

\footnotetext{
${ }^{1}$ Joan C. Henderson, 2016. Muslim Travellers, Tourism Industry Responses and the Case of Japan. Tourism Recreation Research Vol. 41 No. 3, hlm. 339-47.

${ }^{2}$ Ramadhan Razali, Sutan Febriansyah, Ramadhan. 2019. Eksistensi Keadilan Sosial Dalam Keuangan Publik Islam (Kajian Terhadap Kitab Al-Amwal Karya Ad-Dawudi. Jeskape Vol.3 No. 2, hlm. 40-56.

${ }^{3}$ Ramadhan Razali, Sutan Febriansyah, Hilmi. 2020. Pemikiran Ekonomi Al-Maududi Dalam Perspketif Post-Moderanisme. Jurnal Ekonomi Dan Bisnis Vol. 22 No. 1, hlm. 39-46.
} 
masyarakat sendiri. Pariwisata halal masih menjadi kerangka baru bagi pemerintah. Padahal industri halal merupakan salah satu sumber paling penting dalam meningkatkan Produk Domestik Bruto (PDB) bagi daerah tersebut. ${ }^{4}$

Dalam penelitian ini, peneliti akan memaparkan tentang pengembangan industri halal di Aceh. Selain memaparkan tentang pengembangan industri halal tersebut, penulis juga akan memberikan solusi dalam pengembangan Industri halal tesebut. Diharapkan dengan adanya penelitian ini menjadi sumbangsih bagi pemerintah daerah setempat.

\section{Metode Penelitian}

Penelitian ini merupakan penelitian kualitatif. Adapun metode penelitian yang digunakan dalam penelitian ini adalaah literature review atau telaah literature dari berbagai penelitian sebelumnnya. Metode pengumpulan data yang digunakan adalah pengumpulan data sekunder yang diperoleh dari jurnal, buku dokumentasi, dan laporan-laporan yang berasal dari pihak terkait seperti Badan Pusat Statistik, LPPOM MPU, LPPOM MUI, Dinas Kebudayaan dan Pariwisata Aceh dan pihak-pihak terkait.

Sedangkan metode analisis data yang digunakan dalam penelitian ini adalah metode analisis deskriptif. Data-data yang diperoleh dari berbagai sumber kemudian dianalisis dengan metode analisis deskriptif. Metode ini digunakan dengan menyusun data yang diperoleh kemudian diinterpretasikan serta dianalisis sehingga hasil yang didapatkan mampu menjawab rumusan penelitian.

\section{Tinjauan Pustaka}

Menurut Siddiq Azzam, salah satu faktor pendorong berkembangnya pasar halal global adalah meningkatnya pertumbuhan Muslim di dunia yang semakin pesat. ${ }^{5}$ Pada saat ini populasi Muslim diproyeksikan menjadi 2,1 miliar. Data ini menunjukkan bahwa populasi Muslim sudah mewakili 28,26 persen dari populasi dunia yaitu 2,18 miliar. Pertumbuhan Muslim yang signifikan berimplikasi terhadap kebutuhan industri halal. Kebutuhan industri halal tidak hanya mencakup halal food saja melainkan juga halal tourism, halal travel, dan halal hospitality.

Ditinjau dari pengertian, istilah lain dari industri halal adalah industri syariah atau industri Islam. Secara etimologi, halal didefinisikan sebagai objek atau suatu aktifitas yang diperintahkan oleh Alquran dan Sunnah. Adapun secara terminologi industri mencakup semua barang dan jasa yang diolah atau diproduksi oleh kegiatan ekonomi. Industri halal adalah industri yang menghasilakn barang dan jasa halal menurut syariah. Istilah halal juga digunakan pada makanan halal, dapur, kode pakaian, peralatan makanan, logo, dan sertifikat halal. Anonim dari halal sendiri adalah haram. Untuk menghindari haram, setiap individu mengikuti petunjuk tentang halal dan haram seperti yang diajarkan oleh Alquran dan Sunnah.

Menurut Aan Nasrullah, potensi pasar produk halal di Indonesia sangat besar. bahkan termasuk yang terbesar di dunia. Apalagi penggunaan produk halal di pasar Indonesia semakin meningkat. Tercatat pada tahun 2017 total konsumsi produk halal di Indonesia sebeasar USD 200 miliar atau lebih dari 36\% total konsumsi rumah tangga. Jumlah ini juga setara dengan $20 \%$ PDB Indonesia. ${ }^{6}$ Konsumsi produk halal ini akan terus tumbuh dengan rata-rata pertumbuhan 5,3\%. Pada tahun 2025, diperkirakan tingkat

\footnotetext{
${ }^{4}$ Ramadhan Razali. 2020. Perilaku Konsumen: Hedonisme Dalam Perspektif Islam. Jeskape Vol. 4 No. 1, hlm. 115-24.

${ }^{5}$ Abdullah Azam, Md Siddique E, and MOHA ASRI. 2020. Global Halal Industry: Realities and Opportunities. International Journal of Islamic Business Ethics Vol. 5 No. 1, hlm. 47. 78.

${ }^{6}$ Aan Nasrullah. 2016. Analisis Potensi Industri Halal Bagi Pelaku Usaha Di Indonesia. no. June: 50-
} 
konsumsi produk halal Indonesia akan mencapai USD 330,5 miliar. BAPPENAS menyatakan bahwa total konsumsi yang besar ini mayoritas berasal dari produk impor. Namun, bila kita mampu meningkatkan produksi pada sektor industri halal, kita bisa menekan angka deficit pada neraca perdagangan. bahkan, bukan hal yang mustahil bila kita juga bisa melakukan peningkatan ekspor produk halal. ${ }^{7}$

Implikasi dari hal tersebut demand produk halal akan semakin meningkat di pasar domestik di masa mendatang. Berbicara tentang produk dan wisata halal ada beberapa indikator didalamnya. Menurut Jaelani wisata halal khususnya memiliki indikator diantara lain adalah: konsep budaya dalam kaitannya dengan pariwisata Islam (situs budaya agama Islam). Kedua, pariwisata identik dengan nilai-nilai Islam), meskipun dapat diperluas yang mencakup non-Muslim. Ketiga, wisata religi (ziarah dan kunjungan ke tempat-tempat suci di seluruh dunia Islam. Keempat, pariwisata Islam: suatu pariwisata dengan dimensi moral baru yang didasarkan pada nilai-nilai yang dapat diterima, berdimensi etis dan memiliki standar transcendental. Sedangkan kelima, wisata Islam yaitu perjalanan yang betujuan dengan motivasi "keselamatan" atau kegiatan yang berarti berasal dari motivasi Islam.

Berbeda dengan Nasrullah, Menurut pandangan Abdul Sahib Al-Shakry konsep wisata syariah harus memenuhi beberapa poin berikut: pertama, kebangkitan budaya dan penyebaran nilai-nilai Islam. wisata syariah harus menjadi ikon kebangkitan budaya Islam, sekaligus maklumat bagi dunia bahwa dunia Islam juga terdapat objek-objek wisata yang menggangumkan sekaligus bentuk warisan budaya. Dengan adanya wisata syariah ini, maka masyarakat dunia diperkenalkan terhadap keluhuruan dan kebesaran budaya Islam. kedua, bahwa wisata syariah harus mendatangkan keuntungan ekonomi bagi masyarakat Muslim. Tentu saja ini adalah tujuan pragmatis yang tidak boleh dilupakan. Namun, didalam tujuan pragmatis semacam itu terdapat idealisme yang mulia, yaitu peduli terhadap peningkatan kesejahteraan umat Muslim, yang dalam konteks ini mereka menjadi host. Artinya wisata syariah dikembangkan dengan tujuan untuk meningkatkan kesejahteraan umat Muslim. Ketiga menginginkan supaya wisata syariah tersebut dapat menguatkan kepercayaan diri, identitas, dan keyakinan umat Muslim dalamm menghadapi stereotip negative dibanding kebudayaan dan gaya hidup budaya lain. Artinya berwisata bukan sekedar berbisnis, melainkan gaya hidup, standar prestise suatu kelompok masyarakat. pengembangan wisata halal menjadi alternative bagi industri wisata di Indonesia seiring dengan tren wisata halal yang menjadi bagian dari industri ekonomi Islam global. ${ }^{8}$ Dinamika pariwisata dunia dalam tiga tahun terakhir dipengaruhi oleh peningkatan jumlah perjalanan atar negara dan pertumbuhan perekonomian terutama di kawasan Asia Pasifik. Total wisatawan dunia pada tahun 2014 mencapai 1.110 juta perjalanan luar negeri atau tumbuh 5\% dibandingkan tahun sebelumnya.

Pada tahun 2014 lebih dari 300 juta (27,1\% dari total wisatawan dunia) melakukan wisata ke Asia dan 96,7 juta di antaranya masuk ke Asia Tenggara. Sementara pada tahun 2015 ditengah situasi global yang tidak kondusif, perjalanan wisatawan dunia masih tumbuh 4,5\%. Jadi, pariwisata tetap mengalami pertumbuhan signifikan. Studi tentang wisata halal ini berupaya mengeksplorasi makna pariwisata budaya yang diintegrasikan dengan wisata halal sebagai pengalaman spiritual masyarakat modern. Artinya, meskipun wisata halal ini termasuk bentuk pariwisata kontemporer sebagai fenomena modern, maka pada masyarakat sekuler para wisatawan nampak berupaya memenuhi beberapa kebutuhan spiritual. Hal ini berbeda dengan masyarakat di Indonesia, praktek keagamaan bertujuan

\footnotetext{
${ }^{7}$ Anwar Fathoni, Muhammad, Tasya Hadi Syahputri, Fakultas Ekonomi dan Bisnis, and Universitas Pembangunan Nasional Veteran Jakarta. 2020. Potret Industri Halal Indonesia: Peluang Dan Tantangan. Jurnal Ilmiah Ekonomi Islam Vol. 6 No. 03, hlm. 428-35.

${ }^{8}$ Muis. 2020. Perkembangan Peluang Dan Tantangan Wisata Halal Di Aceh. Jurnal Adabiya Vol. 22 No. 1, hlm. 41.
} 
memenuhi kebutuhan spiritual, termasuk praktik ziarah di Cirebon sebagai bagian dari aspek pariwisata, hal ini menjadi tradisi keagamaan yang sudah berlangsung lama seiring dengan perkembangan sejarah masyarakat Indonesia. Namun, konteks ini akan berbeda jika dikaitkan dengan bidang pariwisata sebagai bagian dari industri atau kegiatan bisnis yang dapat memberikan keuntungan secara ekonomi dan diproyeksikan dalam kebijakan pemerintah untuk meningkatkan pendapatan masyarakat. Pada akhirnya, wisata halal bukan hanya meliputi keberadaan tempat wisata ziarah dan religi, melainkan pula mencakup ketersediaan fasilitas pendukung, seperti restoran dan hotel yang menyediakan makanan halal dan tempat shalat, serta persyaratan lainnya.

Menurut Nanda Rahmi Pasar wisata syariah masih dianggap sebagai untapped market dimana permintaan yang ada belum mampu dipenuhi dan keberadaanya belum dimanfaatkan secara maksimal, sehingga masih memungkinkan untuk adanya penyesuaian dan inovasi.

Tabel 2. Perbedaan Wisata Halal dan Konvensional

\begin{tabular}{|c|c|c|c|c|}
\hline No. & $\begin{array}{l}\text { Item } \\
\text { Perbandingan }\end{array}$ & Konvensional & Religi & Syariah \\
\hline 1 & Objek & $\begin{array}{l}\text { Alam budaya, } \\
\text { heritage, } \\
\text { kuliner }\end{array}$ & $\begin{array}{l}\text { Tempat ibadah, } \\
\text { peninggalan } \\
\text { sejarah }\end{array}$ & Semuanya \\
\hline 2 & Tujuan & Menghibur & $\begin{array}{l}\text { Meningkatkan } \\
\text { spritualitas }\end{array}$ & $\begin{array}{l}\text { Meningkatkan spritualitas } \\
\text { dengan cara menghibur }\end{array}$ \\
\hline 3 & Target & $\begin{array}{l}\text { Menyentuh } \\
\text { kepuasan dan } \\
\text { kesenangan } \\
\text { yang } \\
\text { berdimensi } \\
\text { nafsu, semata- } \\
\text { mata hanya } \\
\text { untuk hiburan }\end{array}$ & $\begin{array}{l}\text { Aspek spiritual } \\
\text { yang bisa } \\
\text { menenangkan } \\
\text { jiwa. Guna } \\
\text { mencari } \\
\text { ketenangan batin }\end{array}$ & $\begin{array}{l}\text { Memenuhi keinginan dan } \\
\text { kesenangan serta } \\
\text { menumbuhkan kesadaran } \\
\text { beragama }\end{array}$ \\
\hline 4 & Guide & $\begin{array}{l}\text { Memahami } \\
\text { dan menguasai } \\
\text { informasi } \\
\text { sehingga bisa } \\
\text { menarik } \\
\text { wisatawan } \\
\text { terhadap objek } \\
\text { wisata }\end{array}$ & $\begin{array}{l}\text { Menguasai } \\
\text { sejarah tokoh } \\
\text { dan lokasi yang } \\
\text { menjadi objek } \\
\text { wisata }\end{array}$ & $\begin{array}{l}\text { Membuat turis tertarik pada } \\
\text { objek sekaligus } \\
\text { membangkitkan spirit religi } \\
\text { wisatawan. Mampu } \\
\text { menjelaskan fungsi dan } \\
\text { peranan syariah dalam } \\
\text { bentuk kebahagiaan dan } \\
\text { kepuasan batin dalam } \\
\text { kehidupan manusia }\end{array}$ \\
\hline 5 & $\begin{array}{l}\text { Fasilitas } \\
\text { Ibadah }\end{array}$ & $\begin{array}{l}\text { Sekedar } \\
\text { pelengkap }\end{array}$ & $\begin{array}{l}\text { Sekedar } \\
\text { pelengkap }\end{array}$ & $\begin{array}{l}\text { Menjadi bagian yang } \\
\text { menyatu dengan objek } \\
\text { pariwisata, ritual ibadah } \\
\text { menjadi bagian paket hiburan }\end{array}$ \\
\hline 6 & Kuliner & Umum & Umum & Spesifik yang halal \\
\hline 7 & $\begin{array}{l}\text { Relasi dengan } \\
\text { masyarakat } \\
\text { dilingkungan } \\
\text { objek wisata }\end{array}$ & $\begin{array}{l}\text { Komplementer } \\
\text { dan hanya } \\
\text { untuk } \\
\text { keuntungan } \\
\text { materi }\end{array}$ & $\begin{array}{l}\text { Kompelementer } \\
\text { da hanya untuk } \\
\text { keuntungan } \\
\text { materi }\end{array}$ & $\begin{array}{l}\text { Integrated, interaksi } \\
\text { berdasarkan pada prinsip } \\
\text { syariah }\end{array}$ \\
\hline 8 & $\begin{array}{l}\text { Agenda } \\
\text { Perjalana }\end{array}$ & Setiap waktu & $\begin{array}{l}\text { Waktu-waktu } \\
\text { tertentu }\end{array}$ & Memperhatikan waktu \\
\hline
\end{tabular}




\section{Sumber : Waharini and Purwantini 2018)9.}

Optimalisasi wisata syariah juga harus didukung oleh sarana dan prasarana syariah. misalnya saja hotel syariah, halal food, dan lain-lain. Menurut Mujahidin Muhammad indikator hotel syariah antara lain adalah: pertama, fasilitas yang diberikan kepada tamu haruslah sesuai dengan syariah. kedua, bagi tamu yang akan check in dengan lawan jenis ini haruslah di diseleksi istri atau suami. Ketiga, pemasaran dibuka tidak hanya untuk kalangan tertentu saja, melainkan untuk semua pihak baik pribadi, kelompok, formal, informal, dengan beragam suku, agama, ras, dan kelompok. Keempat, makanan dan minuman yang disedikan merupakan makanan dan minuman yang keduanya dijamin kehalalannya. Kelima, dekorasi dan ornamen di dalam hotel harus sesuai dengan syariah, misalnya saja dengan adanya bentuk kaligrafi Alquran dan tidak adanya patung-patung. Agar terciptanya budaya syariah, menurut penulis pengawasan dari pemerintah daerah sangat perlu dilakukan. Pengawasan tersebut dapat dilakukan dengan mengoptimalkan dan melaksanakan qanun-qanun tentang kesyariahan di provinsi Aceh.

\section{Hasil dan Diskusi \\ Aceh Sebagai Pengembang Wisata Syariah dan Industri Halal}

Menurut Endro Tri Susdarwono, Indonesia merupakan Negara yang memiliki banyak kota sejarah serta objek wisata yang menawan. ${ }^{10}$ Integrasi keagamaan, norma dan etika pada objek wisata tersebut berpotensi terhadap komersial pasar perjalanan (tourism). Ditinjau dari data, wisata syariah meningkat dari tahun ke tahun (yoy). Menurut penulis optimalisasi pengelolaan wisata halal di dalam negeri mampu meningkatkan Anggaran Pendapatan dan Belanja Negara (APBN). Wisata halal tidak hanya sekedar tempat wisata saja, melainkan juga wisata yang memiliki integrasi nilai-nilai keagamaan serta adat dan budaya. Sehingga dipastikan segala bentuk objek wisata yang ditawarkan sampai berbagai jenis pelayanan jasanya, sesuai dengan aturan-aturan yang Islami dan tidak melanggar larangan-larangan agama.

Industri Halal terutama wisata halal tidak saja berpotensi di Indonesia secara keseluruhan, melainkan juga sangat berpotensi ekonomi di provinsi Aceh. Provinsi pertama yang menerapkan sistem syariah disegala lini ini merupakan pangsa besar pasar industri halal. Selain mayoritas masyarakatnya Muslim, halal food, provinsi Aceh juga memiliki keindahan objek wisata. Keindahan objek wisata yang ditawarkan mampu memancing pelancong baik dalam dan luar negeri. Menurut data yang dilansir oleh BPS, jumlah wisatawan asing meningkat dari tahun ke tahun (yoy). Data tersebut dapat dilihat pada kurva di bawah ini.

\footnotetext{
${ }^{9}$ Faqiatul Mariya dan Anissa Hakim Purwantini Waharini. 2018. Model Pengembangan Industri Halal Food Di Indonesia. Muqtasid: Jurnal Ekonomi Dan Perbankan Syariah Vol. 9 No.1

${ }^{10}$ Tri Endro Sudarwono. 2021. Interaksi Wisata Syariah Dan Pembangunan Ekonomi Di Kota Pusarnya Pulau Jawa Dalam Bentuk Ekonomi Komersial Ganda. Edutourism Journal of Tourism Research Vol. 02 No. 02, hlm. 49-60.
} 
Tabel 3. Jumlah Wisatawan Asing

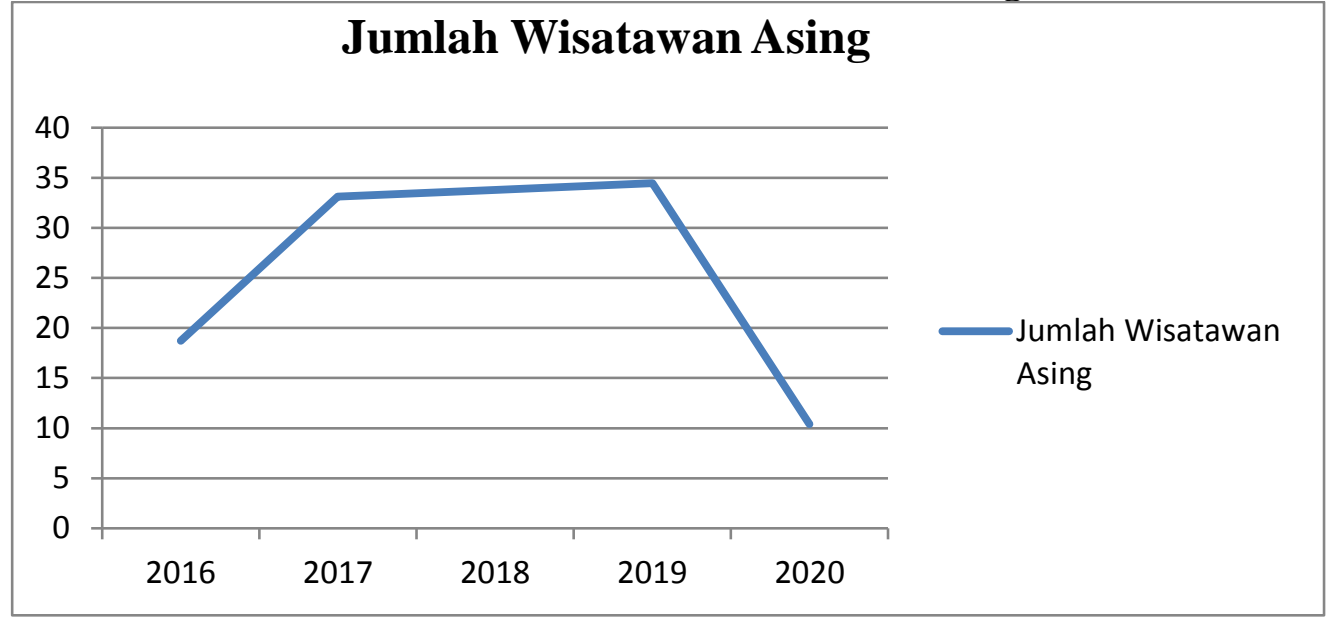

Sumber: BPS www.bps.go.id (data sudah diolah)

Data di atas menunjukkan jumlah turis asing meningkat dari tahun 2016-2019. Pada tahun 2016 jumlah wisatawan yang berkunjung ke Aceh berjumlah 18.738 orang. Pada tahun 2017 wisatawan yang berkunjung ke Aceh berjumlah 33.105 orang. Selanjutnya, pada tahun 2018 wisatawan yang berkunjung ke Aceh berjumlah 33.787 orang. Pada tahun 2019 wisatawan yang berkunjung ke Aceh berjumlah 34.461. Namun, pada tahun tahun 2020 jumlah wisatawan ini menurun menjadi 10.402 orang. Merebaknya virus Covid-19 berimplikasi terhadap menurunnya jumlah wisatawan. Menurunnya jumlah wisatawan tidak hanya terjadi di Aceh saja, melainkan juga terjadi di daerah lainnya.

Dibalik menurunnya jumlah wisatawan yang berkunjung ke aceh pada tahun 2020 . Tampaknya, penerapan kesyariahan di provinsi Aceh menjadi daya tarik wisatawan asing. Hal ini ditunjukkan dengan jumlah wisatawan yang melancong di provinsi Aceh meningkat dari tahun 2016-2019. Wisatawan yang melancong tidak hanya berasal dari negara Muslim, melainkan juga berasal dari negara barat. Dinas Kebudayaan dan Pariwisata Aceh malaporkan mayoritas wisatawan asing yang melancong ke Aceh setidaknya berasal dari 10 negara. Data ini bisa dilihat pada tabel berikut:

Tabel 4. Jumlah Wisatawan di Aceh

\begin{tabular}{|c|l|c|c|c|}
\hline \multirow{2}{*}{ No. } & \multirow{2}{*}{ Negara } & \multicolumn{3}{|c|}{ Jumlah Wisatawan selama 3 tahun terakhir } \\
\cline { 3 - 5 } & & $\mathbf{2 0 1 7}$ & $\mathbf{2 0 1 8}$ & $\mathbf{2 0 1 9}$ \\
\hline 1 & Malaysia & 24.748 & 24.210 & 19.636 \\
\hline 2 & China & 760 & 858 & 1.009 \\
\hline 3 & Jerman & 376 & 282 & 434 \\
\hline 4 & USA & 301 & 274 & 373 \\
\hline 5 & Singapura & 299 & 229 & 416 \\
\hline 6 & Australia & 352 & 275 & 388 \\
\hline 7 & Perancis & 360 & 392 & 499 \\
\hline 8 & Inggris & 334 & 269 & 307 \\
\hline 9 & Thailand & 267 & 268 & 294 \\
\hline 10 & Jepang & - & 227 & 280 \\
\hline
\end{tabular}

Sumber: Dinas Kebudayaan dan Pariwisata Aceh (data sudah diolah)

Data di atas menunjukkan bahwa mayoritas wisatawan selama tiga tahun berasal dari Malaysia. Disusul China, Jerman, Amerika Serikat, Singapura, Australia, Perancis, Inggris, Thailand, dan Jepang. Untuk memaksimalkan brand wisata halal di Aceh, 
beberapa komponen wisata halal, serta kesiapan pemerintah daerah sepertinya harus didiskusikan kembali. Kesiapan-kesiapan pemerintah daerah dan dinas kebudayaan pariwisata aceh antara lain adalah: adanya payung hukum berupa penerbitan qanun wisata halal, keberpihakan anggaran dan dukungan legislatif, road map dan grand design pariwisata halal, infrastruktur yang dapat diandalkan, sertifikasi dan standarisasi halal, program pembekalan kapasitas SDM wisata halal, masyarakat dan budaya, brand promise dan brand experience, serta integrasi marketing brand wisata halal.

Pada dasarnya kondisi Aceh memiliki kelebihan dan juga kelemahan dalam mendukung pariwisata, beberapa isu yang berpotensi terhadap lemahnya sektor pariwisata di Aceh antara lain: faktor demografis (fanatik pada syariat Islam), faktor infrastruktur, faktor komitmen investasi pemerintah dan swasta. Faktor geografis (bukan jalur transit). Aceh terletak di ujung barat Indonesia dan bukan merupakan jalur transit untuk ke berbagai destinasi lainnya. Akibatnya, wisatawan yang ingin mengunjungi Aceh memang harus mengagendakan secara khusus rencana perjalannya dan hal itu tentu akan berdampak pada biaya perjalanan yang harus dibudgetkan secara khusus. Berbeda dengan daerahdaerah lain di Pulau Jawa yang merupakan jalur transit, sehingga kegiatan berwisata dapat dilakukan secara simultan, sehingga ada beberapa komponen biaya yang dapat diefisienkan.

Faktor demografis (fanatik pada syariah Islam), masyarakat Aceh tergolong fanatik terhadap ke-Islamannya dan hal tersebut seringkali menimbulkan rasa ketidaknyaman bagi sebagian wisatawan yang belum melihat langsung Aceh dari dekat dan merasakan sendiri pengalaman berinteraksi dengan masyarakat Aceh dimana kondisi kekhawatiran tersebut dapat sirna sama sekali. Dalam hal ini, ada sebuah pekerjaan rumah yang penting bagi Pemerintah Aceh yang secara konsisten dan berkelanjutan untuk menampilkan nuasa syariah Islam yang penuh dengan kedamaian. Media-media nasional dan internasional turut andil dalam menimbulkan citra negatif tentang pelaksanaan syariah Islam di Aceh dimana cenderung sangat proaktif memberitakan sisi hukuman bagi pelanggar syariat Islam. Padahal hukum tersebut adalah konsekuensi logis dari aturan hukum yang diakui oleh negara. Namun disisi lain juga tantangan bagi pemerintah Aceh agar dapat menarik perhatian media dengan sisi lain dari syariah Islam sehingga dapat berkontribusi positif bagi wisata halal bukan justru menjadi kontra produktif.

Faktor infrastruktur, seperti yang dijelaskan sebelumnya bahwa infrastruktur pariwisata dan sarana pendukung pariwisata masih tergolong belum memadai di Aceh. Sarana-sarana yang ramah Muslim seharusnya tersedia dalam jumlah yang cukup dan dalam kondisi yang layak. Namun kondisi di lapangan masih banyak kita jumpai misalnya di tempat umum seperti warung kopi, masjid, pasar, dan lainnya, belum tersedia sarana ramah Muslim/Muslimah seperti toilet yang belum representatif bagi perempuan maupun kaum difabel, mushalla yang terdapat di kafe, berukuran sangat sempit, serta pedestrian yang kurang ramah bagi pejalan kaki.

\section{Strategi Pengembangan Industri Halal di Aceh}

Menurut Eka Dewi Satriana, dalam Islam pariwisata halal sangat dianjurkan. Anjuran ini termaktub di dalam banyak surat dan ayat misalnya saja di surah Ali-Imran: 137; Al-An'am: 11; Al-Nahl: 36; Al-Naml: 69; Al-'Ankabut: 20; Ar-Rum:9 dan 42; Saba':18; Yusuf: 109; Al-Hajj: 46; Fathir: 44; Ghafhir: 82 dan 21; Muhammad: 10; Yunus: 22; dan Al-Mulk:15. Ayat-ayat tersebut menjelaskan tentang perjalanan dengan tujuan spiritual, fisik, dan sosial. Lebih rincinya, ayat tersebut menjelaskan tentang salah satu strategi penyerahan diri kepada Allah Swt. adalah melihat langsung keindahan dan karunia 
ciptaan-Nya. Secara psikologi, adanya perjalanan meminimalisir stres dan meningkatkan kesehatan. ${ }^{11}$

Republika melansir bahwa kementerian pariwisata (Kemenpar) menyatakan provinsi Aceh menjadi salah satu daerah prioritas dalam pengembangan wisata halal. Untuk mengembangkan pariwisata halal menurut penulis setidaknya membutuhkan beberapa poin dalam pengembangannya. Salah satu strategi yang harus dilakukan oleh pemerintah daerah adalah regulasi penerbitan sertifikasi halal industri halal dan usaha pariwisata yang mudah. Pengembangan industri halal dapat dilakukan diantara lain dengan:

\section{Memberikan sertifikasi halal kepada industri dan usaha pariwisata untuk mendapatkan kepercayaan wisatawan.}

Minimnya sertifikat halal yang dimiliki para pemilik industri halal berimplikasi terhadap kurangnya variasi pemilihan destinasi halal wisatawan. Seharusnya dengan meningkatnya preferensi masyarakat terhadap produksi halal menjadikan keragaman produk halal di pasaran. Variasi produk halal tidak lain untuk memenuhi permintaan masyarakat terhadap produk tersebut. Adapun pendorong akan permintaan produk halal adalah kebutuhan akan pemenuhan syariah Islam dalam perilaku ekonomi dan peningkatan pendapatan masyarakat Muslim.

Besarnya jumlah penduduk Muslim di Indonesia berimplikasi terhadap meningkatnya permintaan produk halal oleh masyarakat. Di Provinsi Aceh sendiri, permintaan produk halal meningkat dari tahun ke tahun. Dengan meningkatnya permintaan produk halal, para pelaku usaha berbondong-bondong mendaftarkan sertifikasi halal. LPPOM Majelis Permusyawaratan Ulama Aceh melaporkan setidaknya ada 4 katagori dalam pemberian sertifikat halal. Kelompok tersebut adalah kelompok industri pengolahan, kelompok rumah potong hewan, kelompok restoran, dapur, dan catering, serta kelompok lain-lain. Jumlah sertifikat di setiap kelompok tersebut dapat dilihat berdasarkan kurva tabel di bawah ini:

Tabel 5. Jumlah Sertifikat Yang Dikeluarkan Pemerintah Aceh

\begin{tabular}{|l|l|r|r|r|r|}
\hline \multirow{2}{*}{ No. } & \multicolumn{3}{|}{ Kelompok Sertifikat Halal } & \multicolumn{4}{|c|}{ Jumlah Sertifikat per Tahun } \\
\cline { 3 - 6 } & & $\mathbf{2 0 1 7}$ & $\mathbf{2 0 1 8}$ & \multicolumn{1}{c|}{$\mathbf{2 0 1 9}$} & \multicolumn{1}{c|}{$\mathbf{2 0 2 0}$} \\
\hline 1 & Kelompok Industri Pengolahan & 127 & 150 & 164 & 139 \\
\hline 2 & Kelompok Rumah Potong Hewan & 10 & 7 & 8 & 2 \\
\hline 3 & $\begin{array}{l}\text { Kelompok Restoran, Dapur, dan } \\
\text { Catering }\end{array}$ & 6 & 12 & 7 & 9 \\
\hline 4 & Kelompok lain-lain & - & 3 & 5 & - \\
\hline
\end{tabular}

Sumber: LPPOM MPU (data sudah diolah)

Data di atas menunjukkan bahwa pada tahun 2017 jumlah sertifikat halal yang dikeluarkan oleh LPPOM MPU berjumlah 143 sertikat. sedangkan jumlah pada tahun 2018 jumlah sertifikat yang dikeluarkan sebanyak 172 sertifikat. Kelompok industri pengolahan pada tahun 2018 berjumlah 150 sertifikat. Sedangkan kelompok rumah potong hewan berjumlah 7 sertifikat. Kelompok restoran, dapur, dan catering berjumlah 12. Serta kelompok lain berjumlah 3. Pada tahun 2019 sertifikat berjumlah 184. Kelompok industri pengolah berjumlah 164 sertifikat. Kelompok rumah potong hewan berjumlah 8 sertifikat.

\footnotetext{
${ }^{11}$ Satriana Eka Dewi. 2018. Wisata Halal: Perkembangan, Peluang, Dan Tantangan. Journal of Halal .Product and Research (JHPR) Vol. 01 No. 02, hlm. 32-43.
} 
Kelompok restoran, dapur, dan catering 7. Kelompok lain-lain berjumlah 5 sertifikat. Pada tahun 2020 jumlah sertifikat yang dikeluarkan oleh LPPOM MPU berjumlah 150 sertifikat, diantara sertifikat tersebut kelompok industri pengolah mengeluarkan 139 sertifikat. Kelompok rumah potong hewan mengeluarkan 2 sertifikat. Kelompok restoran, dapur, dan catering mengeluarkan sebanyak 9 sertifikat. Meningkatnya industri halal berimplikasi terhadap meningkatnya usaha-usaha mikro yang dilakukan oleh masyarakat di Provinsi Aceh.

\section{Rekonstruksi upaya-upaya dan kebijakan yang dilakukan oleh Pemerintah Daerah.}

Kebijakan ini dimaksudkan tidak hanya untuk mempermudah regulasi yang ada, melainkan juga untuk mendukung pengusaha-pengusaha mikro. Menurut penulis salah satu upaya yang harus dilakukan adalah membangun brand marketing. Untuk membangun brand marketing setidaknya Pemerintah daerah memerlukan proses kreatif seperti pembuatan logo, penentuan slogan, dan mendefinisikan pesan yang hendak disampaikan. Pada dasarnya, brand marketing mengintegrasikan brand dengan kegiatan usaha dan berbagai kegiatan kreatif lainnya yang bertujuan untuk membentuk persepsi pelanggan. Seperti yang dilansir oleh Ekrut untuk menjalankan brand marketing setidaknya dibutuhkan beberapa strategi di antaranya adalah: membuat marketing strategy dan marketing plan, memilih tools dan konten yang tepat untuk digital marketing, identifikasi target pelanggan, bangun kerjasama dengan berbagai pihak.

Selain itu, pengajuan sertifikat halal harus dilakukan dengan profesional. Selama ini mekanisme pengajuan sertifikat halal diawali dengan surat pengajuan oleh pelaku usaha kepada BPJPH atau LPPOM, jika belum terbentuk BPJH daerah. Kemudian BPJH menetapkan lembaga pemeriksa halal (LPH). Selanjutnya, LPH menyerahkan hasil pemeriksaan dan pengujian kehalalan produk kepada BPJPH untuk disidangkan internal. Hasil sidang internal disampaikan kepada Majelis Ulama Indonesia (MUI) guna mendapatkan penetapan kehalalaln produk. Jika sidang internal auditor tidak menemukan hal yang menyebabkan produk tidak memenuhi standar kehalalan produk, maka akan ditolak dan selanjutnya pelaku usaha dapat kembali mengajukan setelah semua dirasa cukup. Adapun proses sertifikasi halal dapat dilihat di bagan berikut ini:

Tabel 6. Proses Sertifikasi Halal

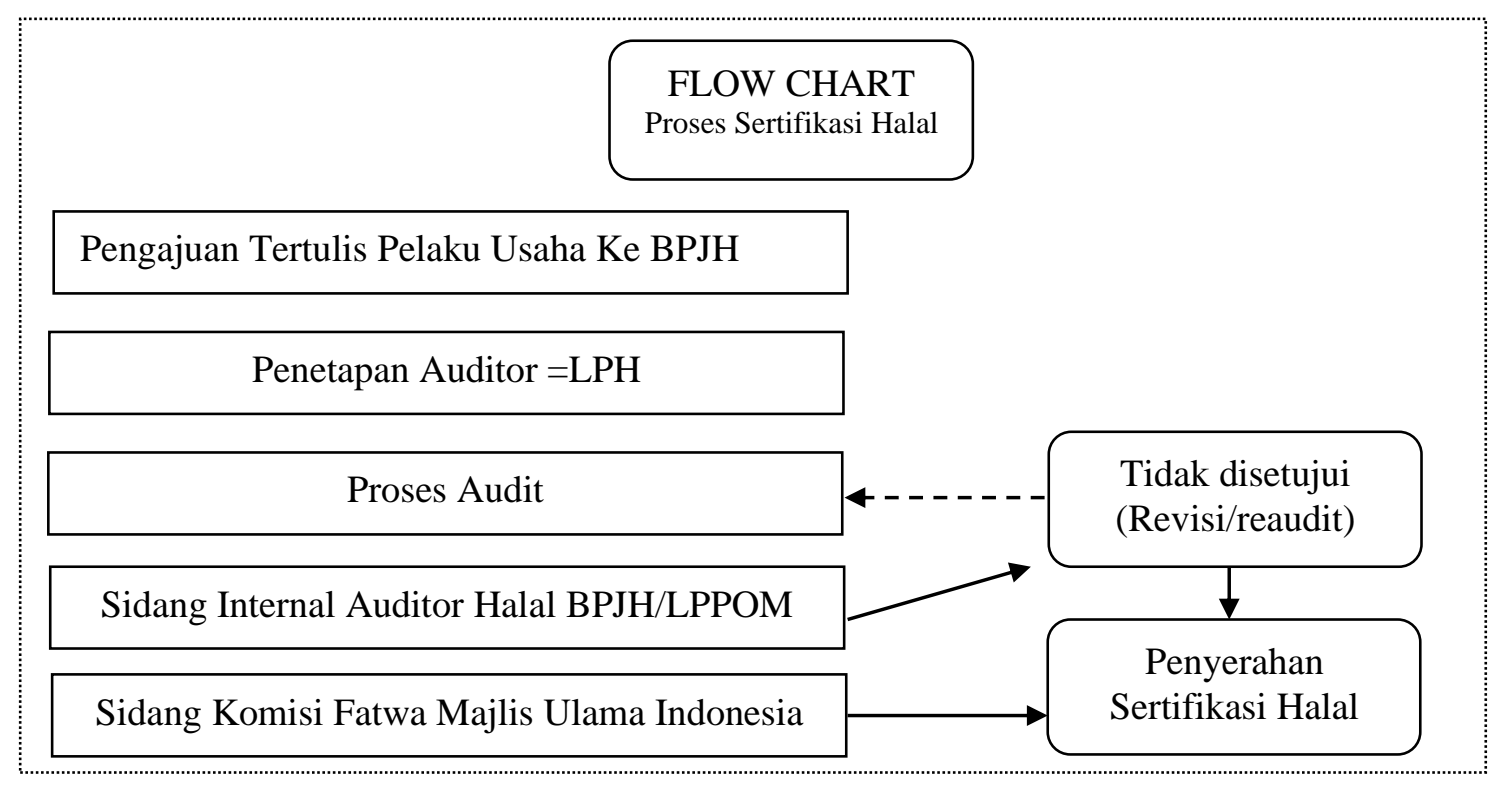

Sumber: Aan Nasrullah (Aan Nasrullah 2016) 


\section{Infrastruktur yang memadai}

Sertifikat halal dan optimalisasi usaha wisata halal saja tidak memadai. Menurut peneliti, untuk mengoptimalkan wisata halal pemerintah harus membangun infrastruktur yang memadai. Para pakar ahli agama merangkum beberapa prinsip-prinsip wisata halal, diantaranya adalah makanan halal, tidak ada minuman keras (mengandung alkohol), tidak menyajikan produk dari babi, tidak ada diskotik, staf pria untuk tamu pria, dan staf wanita untuk tamu wanita, hiburan syar'i, fasilitas ruang ibadah (masjid atau mushalla) yang terpisah antar gender, pakaian yang Islami untuk seragam staf, tersedianya Alquran dan peralatan ibadah (shalat) di kamar, petunjuk kiblat, seni yang tidak menggambarkan bentuk manusia, toilet diposisikan tidak menghadap kiblat, keuangan syariah, dan hotel atau perusahaan pariwisata lainnya harus mengikuti prinsip-prinsip dalam Islam.

Walaupun prinsip-prinsip ini bersifat fleksibel sehingga dapat digunakan tergantung kepentingan. Namun, prinsip makanan halal, produk yang tidak mengandung babi, tidak ada minuman keras, ketersediaan fasilitas ruang ibada, tersedianya Alquran dan peralatan ibadah (shalat) di kamar, petunjuk kiblat, dan pakaian staf yang sopan merupakan hal yang penting bagi wisatawan Muslim. ${ }^{12}$ Pengembangan industri halal juga membutuhkan payung hukum.yang kuat. Pemerintah daerah seharusnya membuat sebuah qanun industri halal. Menurut Rahmat Shaleh, pemerintah Aceh belum menerbitkan Perda atau Qanun. Maka tanpa dasar hukum yang jelas dan tegas pengembangan industri halal akan sulit untuk dilaksanakan. Padahal eksistensi qanun sangat penting bagi pelaku usaha. Lebih jauh lagi Sailendra Wangsa menjelaskan bahwa pemerintah Aceh belum mengeluarkan peraturan gubernur terhadap pembentukan tim terpadu dalam melaksanakan standarisasi halal. Bahkan qanun sistem jaminan produk halal pun masih dianggap kurang terkenal di masyarakat Aceh.

\section{Kesimpulan}

Berdasarkan analisis di atas, peneliti menyimpulkan bahwa optimalisasi industri halal di Provinsi Aceh dapat dilakukan dengan cara: Pertama, memberikan sertifikasi halal kepada industri dan usaha pariwisata untuk mendapatkan kepercayaan wisatawan. Kedua, melakukan rekonstruksi terhadap upaya-upaya dan kebijakan yang dilakukan oleh Pemerintah Daerah dalam rangka mengembangkan industri halal di Aceh. Ketiga, melakukan pembenahan terhadap infrastruktur agar memadai. Dengan adanya ketiga komponen di atas pengembangan industri halal di Aceh akan optimal. Optimalnya industri halal di Provinsi Aceh diharapkan menjadi penggerak bagi roda perekonomian masyarakat Aceh, yang pada akhirnya diharapkan pengangguran dan kemiskinan di Provinsi Aceh akan menurun seiring berkembangnya industri halal.

\section{Daftar Pustaka}

Aan Nasrullah. 2016. Analisis Potensi Industri Halal Bagi Pelaku Usaha Di Indonesia. no. June: $50-78$.

Anwar Fathoni, Muhammad, Tasya Hadi Syahputri, Fakultas Ekonomi dan Bisnis, and Universitas Pembangunan Nasional Veteran Jakarta. 2020. Potret Industri Halal Indonesia: Peluang Dan Tantangan. Jurnal Ilmiah Ekonomi Islam 6 (03): 428-35. http://jurnal.stie-aas.ac.id/index.php/jiedoi:http://dx.doi.org/10.29040/jiei.v6i3.1146.

\footnotetext{
${ }^{12}$ Hariman Syaleh. 2016. Faktor-Faktor Yang Mempengaruhi Minat Wisatawan Berkunjung Ke Kota Bukittinggi. Jurna Ekonomi STIE Agus Salim Vol XX No. 2, hlm. 126-34.
} 
Anwar Fathoni, Muhammad, Tasya Hadi Syahputri, Fakultas Ekonomi dan Bisnis, and Universitas Pembangunan Nasional Veteran Jakarta. 2020. Potret Industri Halal Indonesia: Peluang Dan Tantangan. Jurnal Ilmiah Ekonomi Islam 6 (03): 428-35. http://jurnal.stie-aas.ac.id/index.php/jiedoi:http://dx.doi.org/10.29040/jiei.v6i3.1146.

Auliya, Zakky Fahma, (2019), Factors Affecting Interest in Revisiting Sharia Hotel, Jurnal Al-Qardh, Vol. 4, No. 2, pp. 76-87, doi: https://doi.org/10.23971/jaq.v4i2.1552

Azam, Md Siddique E, and MOHA ASRI Abdullah. 2020. Global Halal Industry: Realities and Opportunities. International Journal of Islamic Business Ethics 5 (1): 47. https://doi.org/10.30659/ijibe.5.1.47-59.

Azam, Md Siddique E, and MOHA ASRI Abdullah. 2020. Global Halal Industry: Realities and Opportunities. International Journal of Islamic Business Ethics 5 (1): 47. https://doi.org/10.30659/ijibe.5.1.47-59.

Faqiatul Mariya, and Anissa Hakim Purwantini Waharini. 2018. Model Pengembangan Industri Halal Food Di Indonesia. Muqtasid: Jurnal Ekonomi Dan Perbankan Syariah 9 (1): 1. https://doi.org/10.18326/muqtasid.v9i1.1-13.

Hafizi, Muhammad Riza., dan Rimbodo, Dyah Sulistiyo., (2019), Pengelolaan Bisnis Perhotelan Syariah, At-Tijaroh: Jurnal Ilmu manajemen dan Bisnis Islam, Vol. 5, No. 1, pp. 52-66, doi: https://doi.org/10.24952/tijaroh.v5i1.1631

Henderson, Joan C. 2016. Muslim Travellers, Tourism Industry Responses and the Case of Japan. Tourism Recreation Research $41 \quad$ (3): 339-47. https://doi.org/10.1080/02508281.2016.1215090.

Lubis, Nurul Izzah. (2019), Analisis Loyalitas Konsumen Produk Berlabel Halal, Jurnal Al-Qardh, Vol. 4, No. 1, pp. 51-59, doi: https://doi.org/10.23971/jaq.v4i1.1661

Joan C, Henderson. 2016. Muslim Travellers, Tourism Industry Responses and the Case of Japan. Tourism Recreation Research $41 \quad$ (3): 339-47. https://doi.org/10.1080/02508281.2016.1215090.

Muis, Muis. 2020. Perkembangan Peluang Dan Tantangan Wisata Halal Di Aceh. Jurnal Adabiya 22 (1): 41. https://doi.org/10.22373/adabiya.v22i1.7456.

Muis, Muis. 2020. Perkembangan Peluang Dan Tantangan Wisata Halal Di Aceh. Jurnal Adabiya 22 (1): 41. https://doi.org/10.22373/adabiya.v22i1.7456.

Nasrullah, Aan. 2016. Analisis Potensi Industri Halal Bagi Pelaku Usaha Di Indonesia. no. June: $50-78$.

Pelu, I. E. A., Kurniawan, R., \& Akbar, W. (2020). Developing Sharia Tourism in Fostering Regional Economic Growth (Study on Sharia Tourism at West Nusa Tenggara). Heritage of Nusantara: International Journal of Religious Literature and Heritage, 9(1), pp. 115-142. https://doi.org/10.31291/hn.v9i1.562

Razali, Ramadhan. 2020. Perilaku Konsumen: Hedonisme Dalam Perspektif Islam, Ramadhan Razali. Jeskape 4 (1): 115-24.

Razali, Sutan Febriansyah, Hilmi, Ramadhan. 2020. Pemikiran Ekonomi Al-Maududi Dalam Perspektif Post-Moderanisme. Jurnal Ekonomi Dan Bisnis 22 (1): 39-46.

Razali, Sutan Febriansyah, Ramadhan. 2019. Eksistensi Keadilan Sosial Dalam Keuangan Publik Islam (Kajian Terhadap Kitab Al-Amwal Karya Ad-Dawudi). Jeskape 3 (2): 40-56. https://ejurnal.iainlhokseumawe.ac.id/index.php/jeskape/article/view/431.

Saleh, Rahmat, and Nur Anisah. 2018. Pariwisata Halal Di Aceh: Gagasan Dan Realitas Di Lapangan. Sahafa Journal of Islamic Communication 1 (2): 79. https://doi.org/10.21111/sjic.v1i2.2849.

Satriana, Eka Dewi. 2018. Wisata Halal: Perkembangan, Peluang, Dan Tantangan. Journal of Halal Product and Research (JHPR) Vol. 01 (02): 32-43.

Syaleh, Hariman. 2016. Faktor-Faktor Yang Mempengaruhi Minat Wisatawan Berkunjung Ke Kota Bukittinggi. Jurnal Ekonomi STIE Agus Salim XX (2): 126-34. 
Jurnal Al-Qardh, Vol. 6, No.1, Juli 2021, hlm. 17-29

Tri, Endro Sudarwono. 2021. Interaksi Wisata Syariah Dan Pembangunan Ekonomi Di Kota Pusarnya Pulau Jawa Dalam Bentuk Ekonomi Komersial Ganda. Edutourism Journal of Tourism Research 02 (02): 49-60. jurnal_edutourism@polnes.ac.id.

\section{Website}

www.bps.gp.id

www.halalmui.or.id

www.republika,co,id 